\title{
Preferences of Different Target Groups of Consumers in Case of Furniture Purchase
}

\section{Sklonosti kupaca pri donošenju odluke o kupnji namještaja}

\author{
Original scientific paper • Izvorni znanstveni rad \\ Received-prispjelo: 22. 5. 2019. \\ Accepted-prihvaćeno: 20. 11. 2019. \\ UDK: $630 * 72 ; 630 * 73$ \\ https://doi.org/10.5552/drvind.2020.1932
}
C) 2020 by the author(s). Licensee Faculty of Forestry, University of Zagreb. This article is an open access article distributed under the terms and conditions of the Creative Commons Attribution (CC BY 4.0) license.

\begin{abstract}
In a market environment where changes are constant, understanding customer buying behaviour is crucial for companies in order to operate both successfully and effectively. We analysed how different age groups and net monthly incomes per household influence consumer decisions in Slovenia, Serbia and Croatia in the case of furniture purchases, when the three main factors are material, price and service. Each factor was further divided into three levels. In the case of material, the respondents could choose between solid wood, chipboard and fibreboard or other materials. In the case of price, they could choose between a low, middle or high price range, and in the case of services, they could choose between pre-sales, sales and after-sales services. With conjoint analysis, we analysed the markets in Slovenia, Serbia and Croatia. The important differences in consumer buying behaviour in these three countries were discovered. The results of the research will serve as a useful basis for wood sector companies to design more successful marketing strategies, which will help them to achieve their goals in different target markets.
\end{abstract}

Keywords: marketing; buying decision process; furniture; conjoint analysis

SAŽETAK • Razumijevanje ponašanja kupaca u današnjemu, vrlo promjenjivom tržišnom okruženju jedan je od odlučujućih elemenata za postizanje uspješnoga i učinkovitoga poslovnog rezultata tvrtke. Osnovni je cilj ovog istraživanja bio utvrditi kako u Sloveniji, Srbiji i Hrvatskoj različita dob potrošača te mjesečni neto prihod njihova kućanstva utječu na donošenje odluke o kupnji namještaja, i to promatrajući tri osnovna faktora proizvoda - materijal od kojega je izrađen, cijenu i uslugu. Nadalje, za svaki faktor proizvoda bile su ponuđene tri mogućnosti odabira. Tako su za faktor materijal izrade proizvoda ispitanici mogli odabrati između masivnog drva i ploča iverica ili ploča vlaknatica te drugih materijala; glede faktora cijena proizvoda ispitanici su se mogli odlučiti za niski, srednji ili visoki cjenovni razred proizvoda, dok su za faktor usluga mogli odabrati između pretprodajne, prodajne i postprodajne usluge. Rezultati su pokazali kako pri kupnji namještaja među promatranim grupama ispitanika postoje razlike u donošenju odluke, i to u sve tri promatrane zemlje. Rezultati provedenog istraživanja moći će poslužiti tvrtkama drvnoindustrijskog sektora za osmišljavanje i izgradnju uspješnih marketinških strategija.

Ključne riječi: marketing; proces donošenja odluke; namještaj; objedinjena analiza

\footnotetext{
${ }^{1}$ Authors are professor and assistant at Biotechnical Faculty, Department of Wood Science and Technology, University of Ljubljana, Ljubljana, Slovenia.

${ }^{2}$ Author is professor at Faculty of Forestry, University of Belgrade, Belgrade, Serbia.

${ }^{3}$ Author is assistant professor at Faculty of Forestry, University of Zagreb, Zagreb, Croatia.

${ }^{4}$ Author is assistant professor at Biotechnical Faculty, University of Ljubljana, Ljubljana, Slovenia.
} 


\section{INTRODUCTION}

\section{UVOD}

\subsection{Definition of the problem}

1.1. Postavljanje problema

A house or apartment is not just a set of rooms but a home, where people spend their free time. That is why we try to arrange such spaces so as to feel good, and here furniture plays an important role. The choice of individual elements of furniture for the kitchen, living room, bedroom, children's bedroom, bathroom, corridor and other rooms, significantly influence the quality of our lives.

Furniture companies are experiencing strong global marketing competition, and thus they are forced to look for new ideas to convince customers to purchase their products. It is important to take into account the most important factors in the process of buying furniture. With this aim they should carry out analyses and surveys, and use their results for easier decision-making.

Research carried out in 2017 (Oblak et al., 2017) showed that three factors are more important than others when making a purchase decision. These are quality, price and additional services, while the delivery time, reputation of the manufacturer and other factors are less important. If furniture companies want to prepare a successful marketing strategy, they need to determine which factor is the most important in the selected target market, worth to be taken into account when developing new products, and to be emphasized in advertising.

We often do not achieve the desired results when analysing consumer decision-making with classical research methods, as these focus on each factor individually, and thus overlook the more complex, interconnected reality of these decisions. This problem can be solved by conjoint analysis, where each product is defined by several factors and then the relative importance of each factor is calculated as well as its value attributed to decision-making. All the necessary data for creating a successful marketing strategy are obtained at one time and holistically. The results of such surveys can be surprising, and can reveal customer desires for products that are different than those currently offered in a particular market.

\subsection{Decision-making process}

1.2. Donošenje odluke

In a market environment where changes are constant, understanding customer buying behaviour is crucial for companies in order to operate both successfully and effectively. The decision-making process consists of a five-step route that consumers need to walk through when deciding which product they will buy (Figure 1). In doing so, they check and evaluate the functional benefit of the product, using a number of criteria for evaluating alternatives, and often spend quite a lot of time before making a final decision. This is especially true for more valuable products, including furniture, where customers choose very carefully between various alternatives (Oblak, 2012)

A better understanding of purchase decisions in the consumer market would enable furniture companies to influence consumers in the individual stages of the decision-making process. Firms thus need to be aware of the factors that affect buying behaviours and know how to convince consumers that a certain product they offer is the best choice. This is why it is necessary to study the needs and desires of potential consumers and at the same time investigate factors that influence the consumers in the process of making a purchase decision.

Research into the effects of purchase decisionmaking in terms of furniture (Al-Azzam and Fattah, 2014; Bednárik and Pakainé Kováts, 2010; Oblak et al., 2017; Olsiaková et al., 2016; Sinclair and Hansen, 2007; Zwierzyński, 2017) show that it is very important for furniture companies to gain a better understanding of such decisions, as this can help them create a combination of products and services that will satisfy consumer needs and desires. To achieve this, it is necessary to assess consumer behaviours at each of the five steps outlined above, as well as the factors that impact these at each level. At the level of recognising consumer needs, a company can prepare market strategies that arouse customers' interest and encourage them to purchase products that will satisfy their needs. Sales personnel can play an important role in the information search phase, and thus they need to be professionally trained and appropriately motivated. Furniture is a product that most people still buy after seeing it first, and if possible

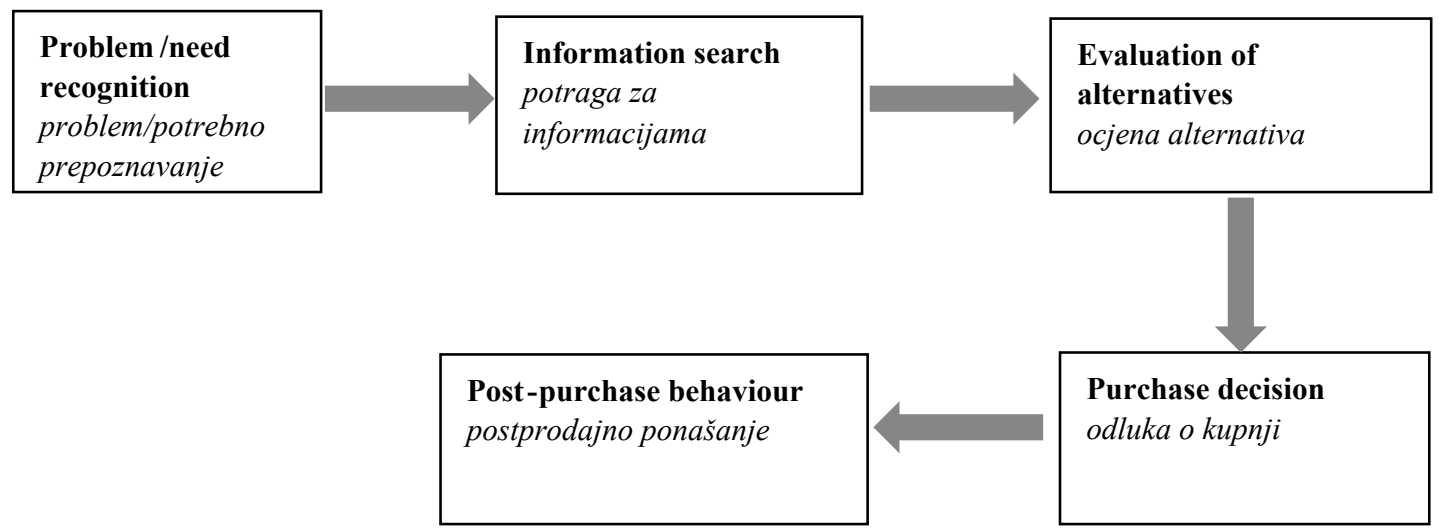

Figure 1 The process of purchase decision-making in the consumer market (Oblak, 2012)

Slika 1. Proces donošenja odluke o kupnji (Oblak, 2012.) 
also testing it prior to making a decision. Potential consumers thus usually find information in furniture stores. Salespersons can also influence consumer decisions in the phase of evaluating alternatives, when customers are perhaps not completely convinced about an item, and a good salesperson is able to persuade them to buy a particular product. In the phase of the purchase decision, there is often a negotiation between the consumer and salesperson regarding the terms and conditions of sale, in particular the price, time and method of payment, the guarantee, delivery, the delivery time, and furniture assembly. If the terms of purchase are acceptable, then an actual purchase will occur. Since it is easier and cheaper to retain already existing customers than acquire new ones, companies should be aware that there is also a preassessment phase in the decision-making process. This often influences a consumer's decision as to whether he/ she will stay faithful to the company or not.

Many studies have been carried out in the field of the decision-making process (Makovec Brencic and Zorko, 2009; Papafotikas et al., 2014; Susjan and Lah, 1996; Warayuanti and Suyanto, 2015), with the results showing that the buying habits of individual consumer groups in different target markets are not the same.

The aim of our survey was thus to determine how consumers of different age groups and with different net monthly incomes per household from Slovenia, Serbia and Croatia make decisions in the case of purchasing furniture. The results are valuable when developing a marketing approach for individual target markets and consumers' groups.

\section{MATERIALS AND METHODS}

\section{MATERIJALI I METODE}

\subsection{Conjoint analysis}

2.1. Objedinjena analiza

Conjoint analysis is one of the most commonly used research method in marketing for analysing consumer needs (Evans, 2008; Green et al., 2001). According to Green and Srinivasan (1990), there were more than 400 commercial uses of conjoint analysis in the early 1980s. Large companies such as Ford, General Electric, General Foods, General Motors and Xerox started to use conjoint analysis for wide spectrum of products, while other companies used it for advertising, competitive analysis, designing new products, market segmentation and positioning of products (Green et al., 2001). In addition to its use for commercial purposes, conjoint analysis has also been applied in a diverse range of areas. However, conjoint analysis is an especially good method for determining consumer preferences. When using other approaches, consumers evaluate each factor of the product separately, while a conjoint analysis gives a more comprehensive view of a certain product. In other words, the researcher asks a consumer to give his/her preferences with regard to a particular product as an assessment of the whole product, and this approach reflects the status of consumers in real life.

In this context, conjoint analysis aims to understand how people make decisions between products or services, so that companies can design new products or services that better meet the basic needs of consumers. It is a powerful tool in determining what drives people to buy a certain product and what the consumer appreciates most in a particular item. However, marketers often have difficulties with understanding the word "conjoin". It refers to the fact that the characteristics of products or services are CONsidered JOINTly by consumers. In fact, the adjective "conjoint" derives from the verb "to conjoin", which means "to join together". The key feature of conjoint analysis is that respondents evaluate product profiles, composed of several pooled elements (factors). Depending on the way in which respondents evaluate the combination of elements, we can understand their preferences for a particular product factor that would be the sum of all ratings (Orme, 1998). Conjoint analysis has thus become one of the most popular ways to develop and test new concepts, because it has many different applications.

Various authors have discussed steps or implementation of conjoint analysis (Green and Srinivasan, 1978; Gustafsson et al., 2013; Hair et al., 1998; Zadnik Stirn, 1998). Each author has a slightly different approach, but in general they are very similar to each other. In order to carry out conjoint analysis properly, the following steps should be followed:

(1) definition of research problem

(2) definition of factors and their levels

(3) definition of the basic model and collecting data

(4) evaluation of the obtained data and interpretation of the results.

The basic concept of conjoint analysis is that it is possible to describe each product or service with a certain relevant number of properties and property levels - giving the product or service profile. Gustafsson et al. (2013) noted that, when drawing up the levels, we have to pay attention to four criteria, as the levels of individual factors must be:

- independent (the value of one level should not depend on another)

- focused (levels should be focused on one factor)

- real (the levels can be defined numerically or descriptively) and

- in balance (a factor will gain importance if it has multiple levels, and it is therefore better if all factors have the same number of levels).

An example of a conjoint analysis profile is shown in Figure 2.

A discrete model was used for our research. This is used when the factor levels are represented by discrete values and the shape of the preference function of factor levels is unknown. This is true for the factors examined in this work (material, price, services), and it can be concluded that the relationships between the relative benefits are discrete. In this case, the IBM SPSS Statistics 25 software is used to calculate the relative usefulness of each factor:

$$
u_{j k}= \begin{cases}a_{j k}, & k=1,2, \ldots, \mathrm{k}_{j}-1 \\ \sum_{j=1}^{k_{j}-1} a_{j k}, & k=k_{j}\end{cases}
$$




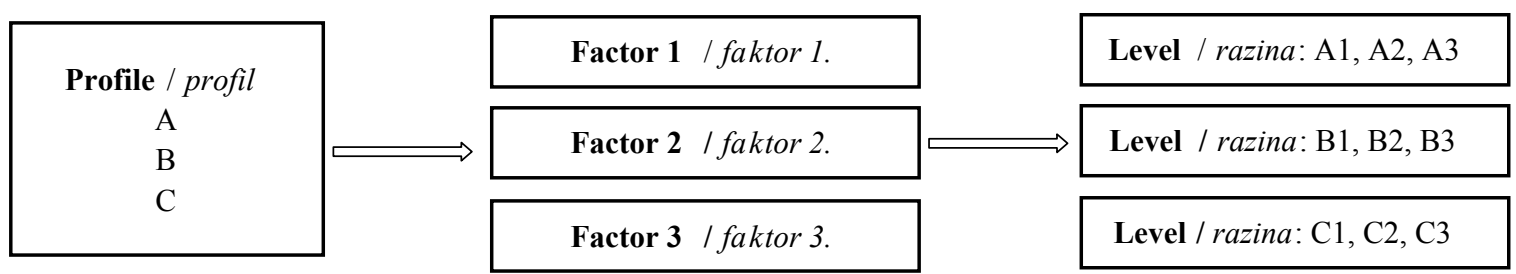

Figure 2 An example of a conjoint analysis profile

Slika 2. Primjer profila objedinjene analize

$u_{j k}$ - the relative usefulness of the $k$-level factor $j$

$a_{j k}-$ level of $k$-discrete factor $j=1, \ldots, p$

$k_{j}$ - the number of $j$ levels of this discrete factor

$p-$ the number of discrete factors

We used the method of simultaneous assessment of all factors (full-profile), or a factorial design. With this method, the offer of possible product concepts is described with a combination of all the levels of the value of each product properties.

\subsection{Definition of research problem}

2.2. Definicija problema istraživanja

Psychologists, sociologists, economists and other researchers usually study purchase decision-making in relation to the different characteristics of consumers. Many authors have studied the influence of various factors on buying behaviour and decisions (Jaakkola, 2007; Neetu and Ashish, 2015; Olsiaková et al., 2016; Ramya and Mohamed Ali, 2016; Rani, 2014; von Helversen et al., 2018; Xu and Chen, 2017). In our research, special attention was paid to age of consumers and their net monthly income per household.

Age undoubtedly affects purchasing decisions, especially when buying more valuable products, such as furniture. People in different periods of their life buy different products and services. This can also be the consequence of a change in lifestyle of the individual or reference group to which the individual belongs.

The net monthly income of the household or its financial situation directly affects the product an individual can afford. The level of income defines the standard of living of an individual, and in particular how much can be spent after meeting the basic needs. Habjančič and Ušaj (2003) found out that consumers have their own idea of the lowest and highest acceptable prices of a product. A price that is lower than the lower limit can make consumers suspicious of the quality and origin of the product. In contrast, when the price exceeds the upper limit, the product is seen as unavailable.

\subsection{Factor selection}

2.3. Odabir faktora

The most important step in conjoint analysis is choosing the factors for the focal products and defining their levels. Factors in conjoint analysis are the characteristics that describe the product and define it in relation to competing products. A factor is a general feature of the focal product or service. Referring to Oblak et al. (2017), we chose three factors for this study: material, price and services. Each factor consists of different levels. The material factor includes furniture made of solid wood, made of chipboard or fibreboard, and made of other materials. The price factor is divided into low, middle and high price ranges. The services factor consists of pre-sales services (professional consulting, computer images of the furniture in their home, measurements at home, etc.), sales services (payment benefits, such as a discount on cash payments, instalment payments, etc.) and after-sales services (delivery, furniture assembly, warranty, etc.).

In this study Factor 1 stands for material, Factor 2 for price and Factor 3 for services. Factor 1 (material) is further divided into three levels: furniture made of solid wood, furniture made of chipboard or fibreboard, and furniture made of other materials (plastics, artificial mass, and so on). The levels of Factor 2 (price) were: low price range, middle price range and high price range. The levels of Factor 3 (services) were: presales, sales services and after-sales.

A random profile for conjoint analysis in our case is shown in Figure 3.

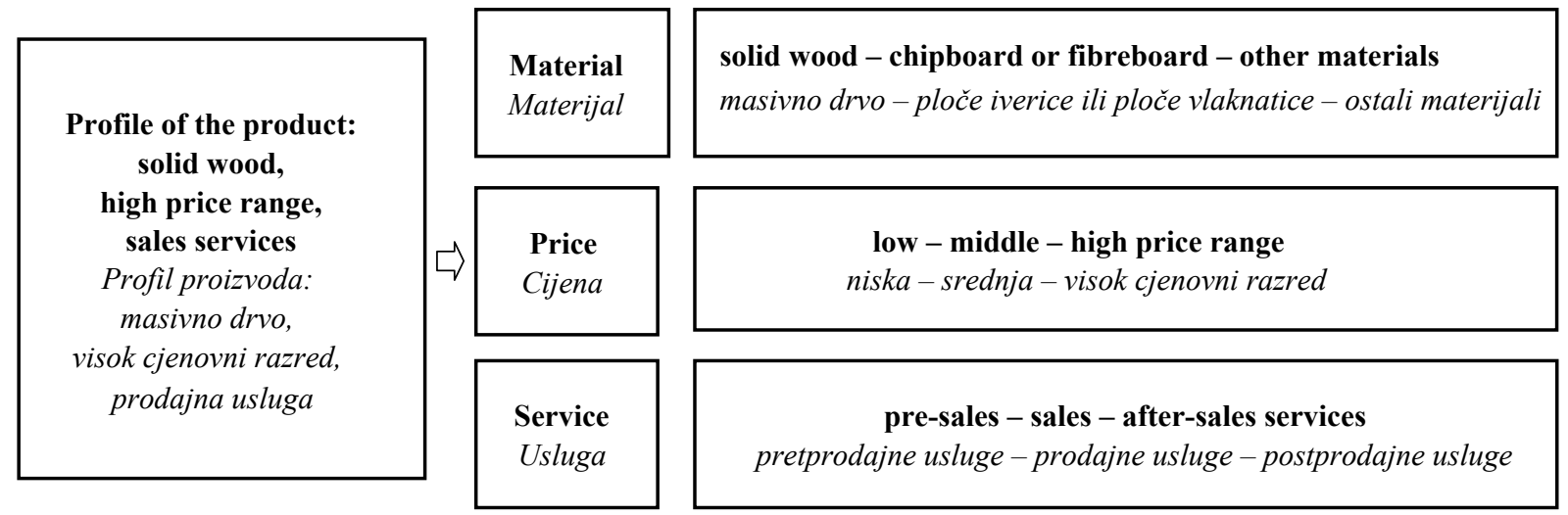

Figure 3 A random profile for our case of conjoint analysis

Slika 3. Slučajno odabrani profil za objedinjenu analizu 
From the given factors and their levels, we created $3 \times 3 \times 3=27$ different combinations or product profiles. Table 1 shows all 27 combinations.

2.4 Questionnaire and data collection

2.4. Anketni upitnik i prikupljanje podataka

For the purpose of our analysis, we used data obtained via a questionnaire. We compiled a short ques- tionnaire, which was divided into two parts. The first part consisted of two questions, which determined the age of the respondents and the net monthly income in their household. In the second part, the respondents had to classify 27 profiles or manufactured furniture concepts, from the most to least favourable one.

The survey was carried out among potential furniture consumers in Slovenia, Serbia and Croatia. Data

Table 1 Combinations of factors and their levels, or profiles, of various products

Tablica 1. Kombinacija faktora i njihovih razina, ili profila, ili kategorija proizvoda

\begin{tabular}{|c|c|}
\hline $\begin{array}{l}\text { Profile } 1 \\
\text { Profil } 1 .\end{array}$ & $\begin{array}{l}\text { solid wood, low price range, pre-sales } \\
\text { masivno drvo, nizak cjenovni razred, pretprodajne usluge }\end{array}$ \\
\hline $\begin{array}{l}\text { Profile } 2 \\
\text { Profil } 2 .\end{array}$ & $\begin{array}{l}\text { solid wood, low price range, sales services } \\
\text { masivno drvo, nizak cjenovni razred, prodajne usluge }\end{array}$ \\
\hline $\begin{array}{l}\text { Profile } 3 \\
\text { Profil } 3 .\end{array}$ & $\begin{array}{l}\text { solid wood, low price range, after-sales } \\
\text { masivno drvo, nizak cjenovni razred, postprodajne usluge }\end{array}$ \\
\hline $\begin{array}{l}\text { Profile } 4 \\
\text { Profil } 4 .\end{array}$ & $\begin{array}{l}\text { chipboard or fibreboard, low price range, pre-sales } \\
\text { ploča iverica ili ploča vlaknatica, nizak cjenovni razred, pretprodajne usluge }\end{array}$ \\
\hline $\begin{array}{l}\text { Profile } 5 \\
\text { Profil } 5 .\end{array}$ & $\begin{array}{l}\text { chipboard or fibreboard, low price range, sales services } \\
\text { ploča iverica ili ploča vlaknatica, nizak cjenovni razred, prodajne usluge }\end{array}$ \\
\hline $\begin{array}{l}\text { Profile } 6 \\
\text { Profil } 6 .\end{array}$ & $\begin{array}{l}\text { chipboard or fibreboard, low price range, after-sales } \\
\text { ploča iverica ili ploča vlaknatica, nizak cjenovni razred, postprodajne usluge }\end{array}$ \\
\hline $\begin{array}{l}\text { Profile } 7 \\
\text { Profil } 7 .\end{array}$ & $\begin{array}{l}\text { other materials, low price range, pre-sales } \\
\text { drugi materijali, nizak cjenovni razred, pretprodajne usluge }\end{array}$ \\
\hline $\begin{array}{l}\text { Profile } 8 \\
\text { Profil } 8 .\end{array}$ & $\begin{array}{l}\text { other materials, low price range, sales services } \\
\text { drugi materijali, nizak cjenovni razred, prodajne usluge }\end{array}$ \\
\hline $\begin{array}{l}\text { Profile } 9 \\
\text { Profil } 9 .\end{array}$ & $\begin{array}{l}\text { other materials, low price range, after-sales } \\
\text { drugi materijali, nizak cjenovni razred, postprodajne usluge }\end{array}$ \\
\hline $\begin{array}{l}\text { Profile } 10 \\
\text { Profil } 10 .\end{array}$ & $\begin{array}{l}\text { solid wood, middle price range, pre-sales } \\
\text { masivno drvo, srednji cjenovni razred, pretprodajne usluge }\end{array}$ \\
\hline $\begin{array}{l}\text { Profile } 11 \\
\text { Profil } 11 .\end{array}$ & $\begin{array}{l}\text { solid wood, middle price range, sales services } \\
\text { masivno drvo, srednji cjenovni razred, prodajne usluge }\end{array}$ \\
\hline $\begin{array}{l}\text { Profile } 12 \\
\text { Profil } 12 .\end{array}$ & $\begin{array}{l}\text { solid wood, middle price range, after-sales } \\
\text { masivno drvo, srednji cjenovni razred, postprodajne usluge }\end{array}$ \\
\hline $\begin{array}{l}\text { Profile } 13 \\
\text { Profil } 13 .\end{array}$ & $\begin{array}{l}\text { chipboard or fibreboard, middle price range, pre-sales } \\
\text { ploča iverica ili ploča vlaknatica, srednji cjenovni razred, pretprodajne usluge }\end{array}$ \\
\hline $\begin{array}{l}\text { Profile } 14 \\
\text { Profil } 14 .\end{array}$ & $\begin{array}{l}\text { chipboard or fibreboard, middle price range, sales services } \\
\text { ploča iverica ili ploča vlaknatica, srednji cjenovni razred, prodajne usluge }\end{array}$ \\
\hline $\begin{array}{l}\text { Profile } 15 \\
\text { Profil } 15 .\end{array}$ & $\begin{array}{l}\text { chipboard or fibreboard, middle price range, after-sales } \\
\text { ploča iverica ili ploča vlaknatica, srednji cjenovni razred, postprodajne usluge }\end{array}$ \\
\hline $\begin{array}{l}\text { Profile } 16 \\
\text { Profil } 16 .\end{array}$ & $\begin{array}{l}\text { other materials, middle price range, pre-sales } \\
\text { drugi materijali, srednji cjenovni razred, pretprodajne usluge }\end{array}$ \\
\hline $\begin{array}{l}\text { Profile } 17 \\
\text { Profil } 17 .\end{array}$ & $\begin{array}{l}\text { other materials, middle price range, sales services } \\
\text { drugi materijali, srednji cjenovni razred, prodajne usluge }\end{array}$ \\
\hline $\begin{array}{l}\text { Profile } 18 \\
\text { Profil } 18 .\end{array}$ & $\begin{array}{l}\text { other materials, middle price range, after-sales } \\
\text { drugi materijali, srednji cjenovni razred, postprodajne usluge }\end{array}$ \\
\hline $\begin{array}{l}\text { Profile } 19 \\
\text { Profil } 19 .\end{array}$ & $\begin{array}{l}\text { solid wood, high price range, pre-sales } \\
\text { masivno drvo, visok cjenovni razred, pretprodajne usluge }\end{array}$ \\
\hline $\begin{array}{l}\text { Profile } 20 \\
\text { Profil } 20 .\end{array}$ & $\begin{array}{l}\text { solid wood, high price range, sales services } \\
\text { masivno drvo, visok cjenovni razred, prodajne usluge }\end{array}$ \\
\hline $\begin{array}{l}\text { Profile } 21 \\
\text { Profil } 21 .\end{array}$ & $\begin{array}{l}\text { solid wood, high price range, after-sales } \\
\text { masivno drvo, visok cjenovni razred, postprodajne usluge }\end{array}$ \\
\hline $\begin{array}{l}\text { Profile } 22 \\
\text { Profil } 22 .\end{array}$ & $\begin{array}{l}\text { chipboard or fibreboard, high price range, pre-sales } \\
\text { ploča iverica ili ploča vlaknatica, visok cjenovni razred, pretprodajne usluge }\end{array}$ \\
\hline $\begin{array}{l}\text { Profile } 23 \\
\text { Profil } 23 .\end{array}$ & $\begin{array}{l}\text { chipboard or fibreboard, high price range, sales services } \\
\text { ploča iverica ili ploča vlaknatica, visok cjenovni razred, prodajne usluge }\end{array}$ \\
\hline $\begin{array}{l}\text { Profile } 24 \\
\text { Profil } 24 .\end{array}$ & $\begin{array}{l}\text { chipboard or fibreboard, high price range, after-sales } \\
\text { ploča iverica ili ploča vlaknatica, visok cjenovni razred, postprodajne usluge }\end{array}$ \\
\hline $\begin{array}{l}\text { Profile } 25 \\
\text { Profil } 25 .\end{array}$ & $\begin{array}{l}\text { other materials, high price range, pre-sales } \\
\text { drugi materijali, visok cjenovni razred, pretprodajne usluge }\end{array}$ \\
\hline $\begin{array}{l}\text { Profile } 26 \\
\text { Profil } 26 .\end{array}$ & $\begin{array}{l}\text { other materials, high price range, sales services } \\
\text { drugi materijali, visok cjenovni razred, prodajne usluge }\end{array}$ \\
\hline $\begin{array}{l}\text { Profile } 27 \\
\text { Profil } 27 .\end{array}$ & $\begin{array}{l}\text { other materials, high price range, after-sales } \\
\text { drugi materijali, visok cjenovni razred, postprodajne usluge }\end{array}$ \\
\hline
\end{tabular}


were collected in several ways: through personal interviews in furniture stores, via paper mail, e-mail and online survey. The survey was conducted from March to June 2018. A total of $37 \%$ of the questionnaires that were sent via paper mail or e-mail were correctly filled in. Regarding different countries, we got 123 responses from Slovenia, 136 from Serbia and 117 from Croatia.

The size of the sample in a conjoint analysis varies from example to example, but most authors (Akaah, 1988; Cattin and Wittink, 1982) agree that anything over 100 respondents is large enough to ensure the reliability of the results if the purpose of the research is to compare the groups surveyed and discover any significant differences.

\section{RESULTS AND DISCUSSION}

\section{REZULTATI I RASPRAVA}

The results obtained in the survey were further analysed using the conjoint analysis and IBM SPSS Statistics 25 software.

The first part of the survey referred to the age of the respondents and monthly income in their household. The results are presented in Tables 2 and 3.

We first analysed the importance of individual factors that influence the decision to purchase an item of furniture. Table 4 shows that the respondents in all three countries evaluated the price as the most important, material as the second and services as the least important factor.

In the second part of the survey, the respondents classified 27 profiles of furniture products, from the most to least liked. Table 5 shows the most liked profiles as classified by respondents in different age groups in Slovenia, Serbia and Croatia.

When choosing the material, most of the respondents from Slovenia and Croatia would choose solid wood, except those from the age group 31-40 years, who would rather choose some other materials. In Serbia, only those younger than 40 years or older than 60 years would choose solid wood. Potential customers in the age group 41-50 years would rather choose other materials, while those in the age group 51-60 years would choose chipboard and fibreboard.

When choosing a price range, the results showed much more diversity. In Slovenia, the respondents aged between 31-40 years and over 60 years preferred high price furniture, while the others preferred the middle price furniture. In Serbia, respondents aged up to 40 years favoured high price furniture. Potential customers aged between 41-60 years would buy middle price furniture and those aged over 60 years preferred low price furniture. In Croatia, high price furniture was chosen by respondents aged up to 30 years and those aged 31-40 years, while low price furniture was favoured by respondents aged between 41-50 years and older than 60 years.

In the case of services, most of the respondents from Slovenia would give priority to sales services, which mainly refer to payment benefits. However, this was not the case for respondents in the age group 31-40 years and those over 60 years, who would favour presales services (expert consulting, computer images of the furniture in their home, measurements at home, etc.). In Serbia, respondents younger than 30 years were more interested in sales services, while other age groups preferred pre-sales services. In Croatia, respondents aged between $31-40$ years put sales services in the first place, while all the other age groups chose pre-sales services.

Table 6 shows the most favoured profiles of furniture products, as classified by respondents with different net monthly incomes per household member in Slovenia, Serbia and Croatia.

Table 2 Age of respondents

Tablica 2. Dob ispitanika

\begin{tabular}{|c|c|c|c|c|c|c|c|c|c|c|c|c|}
\hline \multirow[b]{2}{*}{ Slovenia / Slovenija } & \multicolumn{2}{|c|}{$\begin{array}{l}\text { Up to } 30 \text { years } \\
\text { Do } 30 \text { godina }\end{array}$} & \multicolumn{2}{|c|}{$\begin{array}{c}\mathbf{3 1}-\mathbf{4 0} \text { years } \\
31-40 \text { godina }\end{array}$} & \multicolumn{2}{|c|}{$\begin{array}{c}\mathbf{4 1}-\mathbf{5 0} \text { years } \\
41-50 \text { godina }\end{array}$} & \multicolumn{2}{|c|}{$\begin{array}{l}\mathbf{5 1}-\mathbf{6 0} \text { years } \\
51-60 \text { godina }\end{array}$} & \multicolumn{2}{|c|}{$\begin{array}{c}\text { Over } 60 \text { years } \\
\text { Više od } 60 \text { godina }\end{array}$} & \multicolumn{2}{|c|}{$\begin{array}{c}\text { Total } \\
\text { Ukupno }\end{array}$} \\
\hline & 32 & $26.0 \%$ & 27 & $22.0 \%$ & 23 & $18.7 \%$ & 22 & $17.9 \%$ & 19 & $15.4 \%$ & 123 & $100 \%$ \\
\hline Serbia /Srbija & 34 & & & & 3 & & & & & & 36 & $100 \%$ \\
\hline Croatia / Hrvatska & 38 & $32.5 \%$ & 31 & $26.5 \%$ & 22 & $18.8 \%$ & 16 & $13.7 \%$ & 10 & $8.5 \%$ & 117 & $100 \%$ \\
\hline
\end{tabular}

Table 3 Net monthly income of respondents per household member $(€)$

Tablica 3. Mjesečni neto prihod ispitanika po članu kućanstva (u EUR)

\begin{tabular}{|c|c|c|c|c|c|c|c|c|c|c|c|c|}
\hline & \multicolumn{2}{|c|}{$\begin{array}{c}\text { Up to } 200 \\
\text { Do } 200 \\
\end{array}$} & \multicolumn{2}{|c|}{$\begin{array}{l}\mathbf{2 0 0}-\mathbf{5 0 0} \\
200-500 \\
\end{array}$} & \multicolumn{2}{|c|}{$\begin{array}{l}\mathbf{5 0 1}-\mathbf{1 0 0 0} \\
501-1000\end{array}$} & \multicolumn{2}{|c|}{$\begin{array}{l}\mathbf{1 0 0 1}-\mathbf{1 5 0 0} \\
1001-1500 \\
\end{array}$} & \multicolumn{2}{|c|}{$\begin{array}{l}\text { Over } 1500 € \\
\text { Više od } 1500\end{array}$} & \multicolumn{2}{|c|}{$\begin{array}{c}\text { Total } \\
\text { Ukupno } \\
\end{array}$} \\
\hline Slovenia / Slovenija & 5 & $4.1 \%$ & 32 & $26.0 \%$ & 60 & $48.8 \%$ & 16 & $13.0 \%$ & 10 & $8.1 \%$ & 123 & $100 \%$ \\
\hline Serbia / Srbija & 23 & $16.9 \%$ & 46 & $33.8 \%$ & 35 & $25.7 \%$ & 26 & $19.1 \%$ & 6 & $4.4 \%$ & 13 & $100 \%$ \\
\hline Croatia / Hrvatska & 15 & $12.8 \%$ & 36 & $30.8 \%$ & 33 & $28.2 \%$ & 20 & $17.1 \%$ & 13 & $11.1 \%$ & 117 & $100 \%$ \\
\hline
\end{tabular}

Table 4 Importance of individual factors

Tablica 4. Važnost pojedinih faktora

\begin{tabular}{|l|c|c|c|}
\hline & Slovenia / Slovenija & Serbia / Srbija & Croatia / Hrvatska \\
\hline Material / Materijal & $24.8 \%$ & $23.5 \%$ & $24.5 \%$ \\
\hline Price / Cijena & $67.1 \%$ & $68.3 \%$ & $67.0 \%$ \\
\hline Service / Usluga & $8.1 \%$ & $8.2 \%$ & $8.6 \%$ \\
\hline
\end{tabular}


Table 5 The most preferred furniture product profiles by different age groups in three countries (Slovenia, Serbia and Croatia) Tablica 5. Najčešće odabirane vrste namještaja prema različitim dobnim kategorijama ispitanika u promatranim zemljama (Sloveniji, Srbiji i Hrvatskoj)

\begin{tabular}{|c|c|c|c|c|c|}
\hline \multicolumn{6}{|c|}{ Age / Starost } \\
\hline & Up to $30 / D o 30$ & $31-40$ & $41-50$ & $51-60$ & Over 60 / Preko 60 \\
\hline $\begin{array}{l}\text { Slovenia } \\
\text { Slovenija }\end{array}$ & $\begin{array}{c}\text { solid wood } \\
\text { middle price class } \\
\text { sales services } \\
\text { masivno drvo, } \\
\text { srednji cjenovni razred, } \\
\text { prodajna usluga }\end{array}$ & $\begin{array}{c}\text { other materials } \\
\text { high price class } \\
\text { sales services } \\
\text { ostali materijali, } \\
\text { visok cjenovni razred, } \\
\text { prodajna usluga }\end{array}$ & $\begin{array}{c}\text { solid wood } \\
\text { middle price size } \\
\text { presales services } \\
\text { masivno drvo, } \\
\text { srednji cjenovni razred, } \\
\text { pretprodajna usluga }\end{array}$ & $\begin{array}{c}\text { solid wood } \\
\text { middle price class } \\
\text { sales services } \\
\text { masivno drvo, } \\
\text { srednji cjenovni razred, } \\
\text { prodajna usluga }\end{array}$ & $\begin{array}{c}\text { solid wood } \\
\text { high price class } \\
\text { presales services } \\
\text { masivno drvo, } \\
\text { visok cjenovni razred, } \\
\text { pretprodajna usluga }\end{array}$ \\
\hline $\begin{array}{l}\text { Serbia } \\
\text { Srbija }\end{array}$ & $\begin{array}{c}\text { solid wood } \\
\text { high price class } \\
\text { sales services } \\
\text { masivno drvo, } \\
\text { visok cjenovni razred, } \\
\text { prodajna usluga }\end{array}$ & $\begin{array}{c}\text { solid wood } \\
\text { high price class } \\
\text { presales services } \\
\text { masivno drvo, } \\
\text { visok cjenovni razred, } \\
\text { pretprodajna usluga }\end{array}$ & $\begin{array}{c}\text { other materials } \\
\text { middle price class } \\
\text { presales services } \\
\text { ostali materijali, } \\
\text { srednji cjenovni razred, } \\
\text { pretprodajna usluga }\end{array}$ & $\begin{array}{l}\text { chipboard or fibreboard } \\
\text { middle price class } \\
\text { presales services } \\
\text { ploče iverice ili } \\
\text { vlaknatice, } \\
\text { srednji cjenovni razred, } \\
\text { pretprodajna usluga }\end{array}$ & $\begin{array}{c}\text { solid wood } \\
\text { low price class } \\
\text { presales services } \\
\text { masivno drvo, } \\
\text { nizak cjenovni razred, } \\
\text { pretprodajna usluga }\end{array}$ \\
\hline $\begin{array}{l}\text { Croatia } \\
\text { Hrvatska }\end{array}$ & $\begin{array}{c}\text { solid wood } \\
\text { high price class } \\
\text { presales services } \\
\text { masivno drvo, visok } \\
\text { cjenovni razred, } \\
\text { pretprodajna usluga }\end{array}$ & $\begin{array}{c}\text { other materials } \\
\text { middle price class } \\
\text { sales services } \\
\text { ostali materijali, } \\
\text { srednji cjenovni razred, } \\
\text { prodajna usluga }\end{array}$ & $\begin{array}{c}\text { solid wood } \\
\text { low price size } \\
\text { presales services } \\
\text { masivno drvo, } \\
\text { nizak cjenovni razred, } \\
\text { pretprodajna usluga }\end{array}$ & $\begin{array}{l}\text { solid wood } \\
\text { high price class } \\
\text { presales services } \\
\text { masivno drvo, } \\
\text { visok cjenovni razred, } \\
\text { pretprodajna usluga }\end{array}$ & $\begin{array}{c}\text { solid wood } \\
\text { low price class } \\
\text { presales services } \\
\text { masivno drvo, } \\
\text { nizak cjenovni razred, } \\
\text { pretprodajna usluga }\end{array}$ \\
\hline
\end{tabular}

When choosing a material, the respondents from Slovenia and Serbia whose monthly income per household member was less than 1000 euros would choose furniture made of solid wood, while those with a higher income chose furniture made of other materials.

The majority of respondents from Croatia would choose solid wood, with the exception of those whose net income was in the range of 501-1000 euros.
When choosing the favoured price ranges of furniture, the opinions of the respondents from three countries were the same. Respondents whose monthly net income per household member was less than 500 euros would choose furniture in the low price range, while those with a higher monthly income (501 euros or more) would choose furniture from the high price range. Most of the respondents from Slovenia and Ser-

Table 6 The most popular furniture product profiles classified by respondents with different net monthly incomes from three countries (Slovenia, Serbia and Croatia)

Tablica 6. Najčešće odabirane vrste namještaja prema različitim kategorijama mjesečnih neto prihoda ispitanika u promatranim zemljama (Sloveniji, Srbiji i Hrvatskoj)

\begin{tabular}{|c|c|c|c|c|c|}
\hline \multicolumn{6}{|c|}{$\begin{array}{l}\text { Average household net income per household member }(\boldsymbol{(}) \\
\text { Prosječni neto prihod po članu kućanstva (u EUR) }\end{array}$} \\
\hline & $\begin{array}{l}\text { Up to } 200 \\
\text { Do } 200\end{array}$ & $\begin{array}{l}\mathbf{2 0 0}-\mathbf{5 0 0} \\
200-500\end{array}$ & $\begin{array}{r}\mathbf{5 0 1}-\mathbf{1 0 0 0} \\
501-1000\end{array}$ & $\begin{array}{r}\mathbf{1 0 0 1}-\mathbf{1 5 0 0} \\
1001-1500\end{array}$ & $\begin{array}{l}\text { Over } \mathbf{1 5 0 0} \\
\text { Više od } 1500\end{array}$ \\
\hline $\begin{array}{l}\text { Slovenia } \\
\text { Slovenija }\end{array}$ & $\begin{array}{c}\text { solid wood } \\
\text { low price class } \\
\text { presales services } \\
\text { masivno drvo, } \\
\text { nizak cjenovni razred, } \\
\text { pretprodajna usluga }\end{array}$ & $\begin{array}{c}\text { solid wood } \\
\text { low price class } \\
\text { presales services } \\
\text { masivno drvo, } \\
\text { nizak cjenovni razred, } \\
\text { pretprodajna usluga }\end{array}$ & $\begin{array}{c}\text { solid wood } \\
\text { high price class } \\
\text { presales services } \\
\text { masivno drvo, } \\
\text { visok cjenovni razred, } \\
\text { pretprodajna usluga }\end{array}$ & $\begin{array}{c}\text { other materials } \\
\text { high price class } \\
\text { presales services } \\
\text { ostali materijali, } \\
\text { visok cjenovni razred, } \\
\text { pretprodajna usluga }\end{array}$ & $\begin{array}{c}\text { other materials } \\
\text { high price class } \\
\text { sales services } \\
\text { ostali materijali, } \\
\text { visok cjenovni razred, } \\
\text { prodajna usluga }\end{array}$ \\
\hline $\begin{array}{l}\text { Serbia } \\
\text { Srbija }\end{array}$ & $\begin{array}{l}\text { solid wood } \\
\text { low price class } \\
\text { presales services } \\
\text { masivno drvo, } \\
\text { nizak cjenovni razred, } \\
\text { pretprodajna usluga }\end{array}$ & $\begin{array}{c}\text { solid wood } \\
\text { low price class } \\
\text { presales services } \\
\text { masivno drvo, } \\
\text { nizak cjenovni razred, } \\
\text { pretprodajna usluga }\end{array}$ & $\begin{array}{c}\text { solid wood } \\
\text { high price class } \\
\text { presales services } \\
\text { masivno drvo, } \\
\text { visok cjenovni razred, } \\
\text { pretprodajna usluga }\end{array}$ & $\begin{array}{c}\text { other materials } \\
\text { high price class } \\
\text { presales services } \\
\text { ostali materijali, } \\
\text { visok cjenovni razred, } \\
\text { pretprodajna usluga }\end{array}$ & $\begin{array}{c}\text { other materials } \\
\text { high price class } \\
\text { sales services } \\
\text { ostali materijali, } \\
\text { visok cjenovni razred, } \\
\text { prodajna usluga }\end{array}$ \\
\hline $\begin{array}{l}\text { Croatia } \\
\text { Hrvatska }\end{array}$ & $\begin{array}{c}\text { solid wood } \\
\text { low price class } \\
\text { sales services } \\
\text { masivno drvo, } \\
\text { nizak cjenovni razred, } \\
\text { prodajna usluga }\end{array}$ & $\begin{array}{c}\text { solid wood } \\
\text { low price class } \\
\text { presales services } \\
\text { masivno drvo, } \\
\text { nizak cjenovni razred, } \\
\text { pretprodajna usluga }\end{array}$ & $\begin{array}{l}\text { other materials high } \\
\text { price class } \\
\text { presales services } \\
\text { ostali materijali, } \\
\text { visok cjenovni razred, } \\
\text { pretprodajna usluga }\end{array}$ & $\begin{array}{l}\text { solid wood } \\
\text { high price } \\
\text { class presales services } \\
\text { masivno drvo, } \\
\text { visok cjenovni razred, } \\
\text { pretprodajna usluga }\end{array}$ & $\begin{array}{c}\text { solid wood } \\
\text { high price } \\
\text { class presales services } \\
\text { masivno drvo, } \\
\text { visok cjenovni razred, } \\
\text { pretprodajna usluga }\end{array}$ \\
\hline
\end{tabular}


bia whose monthly income per household member was less than 1500 euros were more interested in pre-sales services, while those with a higher monthly income per household (more than 1500 euros) mostly chose sales services. This result was quite interesting because sales services consist of payment benefits. The situation in Croatia was a little different. The respondents whose monthly income per household member did not exceed 200 euros would focus on sales services, while those whose monthly income per household member was more than 200 euros would choose pre-sales services.

Based on the results presented above, furniture companies will be able to develop better marketing strategies for these target markets. In order to achieve its marketing objectives, a company needs to develop a marketing strategy by working on two key activities segmentation of the target markets and creating a marketing offer for each target market. The proper choice of target markets is necessary to achieve specific marketing objectives. Many companies are unsuccessful in a particular market because they either ignore this activity or misjudge the target market. McCarthy (1978) brought together various marketing instruments that can be used to achieve a specific objective into four elements, named the 4Ps of marketing (product, price, place, promotion). A company, depending on the needs of the target market, changes the volume and quantity of each of the listed components. There are many possibilities how to achieve this objective. When a company gathers information about the target markets, it must decide how to assign the budget for marketing to the various parts of the marketing approach, in order to satisfy the target consumers as much as possible. In doing so, all four elements - product, price, place, and promotion - play an important role.

The results of our research, which are based on survey data from three countries and their target markets, show that the income and age of potential consumers affect their buying preferences. It is, therefore, necessary for companies to segment these three markets. This means that businesses should split the entire, heterogeneous market into market segments, groups of consumers with similar needs to buy certain product, as consumers are too heterogeneous in their own preferences, needs and purchasing power to be considered as one body. The main criteria for segmentation should be income and age. Companies should further decide whether to adopt a multi-segment approach, which means that they focus their marketing activities on a few segments and create a specific marketing offer for each of them. However, they can also decide to follow a focused approach in which all their marketing activities focus on only one market segment. This approach is recommended for smaller furniture companies interested in smaller market segments. This is how they can target small groups of consumers with expectations that such companies can best meet their specific needs.

\section{CONCLUSIONS}

4. ZAKLJUČAK

There are few wood products that are purchased without customers going through a long decision pro- cess. Nevertheless, furniture companies can influence the purchase decisions that consumer make, drawing them away from competing products. For this reason, companies must know well their customers and their particular desires, perceptions and behaviours during the decision-making process.

Conjoint analysis is one of the most commonly used methods for determining consumer preferences. The key advantage of such approach is its assumption that the consumer compares and evaluates the whole spectrum of characteristics and benefits associated with a product or service at the same time (i.e., jointly), with greater or lesser weight given to a certain property of the product or service at the expense of other characteristics. The basic idea of conjoint analysis is that each product or service can be described with thus specific number of properties and property levels - this producing product or service profiles.

Another important advantage of conjoint analysis is that the data collected with a conjoint survey can also be used for modelling. By changing the elements of a marketing offer, we can not only determine the most attractive combinations, but also predict what kind of response can be expected if a competitor chooses to offer new and improved product or service. The number of simulations and scenarios is endless. In the scenario analysis, we can also control external factors, such as the extent of promotion, intensity of advertising, coverage of the market, and so on.

The aim of our research was to find out how age and monthly net income per household affect purchasing decision-making in the case of furniture in Slovenia, Serbia and Croatia, when consumers choose between different materials, price ranges and services. We found that there are significant differences in the purchasing behaviour of potential furniture consumers in Slovenia, Serbia and Croatia with the exception of price range, where the opinions of the respondents in these three countries were similar.

The findings of this research will help furniture companies, which operate in three target markets, Slovenia, Serbia and Croatia, to design better their marketing strategies. A successful combination of promotional content components can be a decisive factor in achieving a company's goals and increasing its competitive advantages.

\section{Acknowledgements - Zahvala}

The authors acknowledge the financial support from the Slovenian Research Agency (research core funding No. P4-0015 and P4-0059).

\section{REFERENCES}

\section{LITERATURA}

1. Akaah, I. P., 1988: A conjoint investigation of the relative importance of risk relievers in direct marketing. Journal of Advertising Research, 28 (4): 38-44.

2. Al-Azzam, A. F. M.; Fattah, M., 2014: Evaluating Effect of Social Factors Affecting. Consumer Behavior in Purchasing Home Furnishing Products in Jordan. British Journal of Marketing Studies, 2 (7): 80-94. 
3. Bednárik, É.; Pakainé Kováts, J., 2010: Consumer behaviour model on the furniture market Acta Silvatica Et Lignaria Hungarica, 6: 75-88.

4. Cattin, P.; Wittink, D. R., 1982: Commercial Use of Conjoint Analysis: A Survey. Journal of Marketing, 46 (3): 44-53. doi: 10.2307/1251701.

5. Evans, C., 2008: Consumer preferences for watermelons: A conjoint analysis. Faculty of Auburn University.

6. Green, P. E.; Krieger, A. M.; Wind, Y., 2001: Thirty Years of Conjoint Analysis: Reflections and Prospects. Interfaces, 31 (3_supplement): S56-S73. doi: 10.1287 /inte.31.3s.56.9676.

7. Green, P. E.; Srinivasan, V., 1978: Conjoint Analysis in Consumer Research: Issues and Outlook. Journal of Consumer Research, 5 (2): 103-123. doi: 10.1086/208721.

8. Green, P. E.; Srinivasan, V., 1990: Conjoint analysis in marketing: new developments with implications for research and practice. Journal of Marketing, 54 (4): 3-19.

9. Gustafsson, A.; Herrmann, A.; Huber, F., 2013: Conjoint measurement: Methods and applications: Springer Science \& Business Media.

10. Habjanic, D.; Usaj Hvalic, T.; Peljhan, L.; Mocivnik, M., 2003: Osnove trzenja. Ljubljana: DZS.

11. Hair, J. F.; Anderson, R. E.; Tatham, R. L.; Black, W. C., 1998: Multivariate data analysis. Upper Saddle River: Prentice-Hall.

12. Jaakkola, E., 2007: Purchase decision-making within professional consumer services: Organizational or consumer buying behaviour? Marketing Theory, 7 (1): 93108. doi: 10.1177/1470593107073847.

13. Makovec Brencic, M.; Zorko, A., 2009: Marketing monitor: a new measurement instrument of consumer and company behaviour in Slovenia. $3^{\text {rd }}$ International Scientific Conference Marketing Theory Challenges in Transitional Societies, Maribor, Slovenia, September $24^{\text {th }}-$ 25 $5^{\text {th }}, 2009:$ 177-182.

14. McCarthy, E. J., 1978: Basic marketing: a managerial approach: RD Irwin.

15. Neetu, J.; Ashish, D., 2015: Influence of Children on Family Buying Decisions: Moderating role of Demographic Factors. ELK's International Journal of Marketing - UGC Approved, 6 (3): 43-58. doi: 10.16962/EAPJMRM/6 34.

16. Oblak, L., 2012: Trzenje lesnih izdelkov in storitev. Ljubljana: Biotehniska fakulteta, Oddelek za lesarstvo.

17. Oblak, L.; Pirc Barčić, A.; Klarić, K.; Kitek Kuzman, M.; Grošelj, P., 2017: Evaluation of Factors in Buying Decision Process of Furniture Consumers by Applying AHP Method. Drvna industrija, 68 (1): 37-43.

18. Olsiaková, M.; Loucanová, E.; Palus, H., 2016: Monitoring changes in consumer requirements for wood products in terms of consumer behavior. Acta Facultatis Xylologiae, Zvolen, Res Publica Slovaca, 58 (1): 137.
19. Orme, B., 1998: Sample size issues for conjoint analysis studies. Sawthooth Software Research paper Series Squim, WA, USA: Sawthooth Software Inc, 10.

20. Papafotikas, I.; Chatzoudes, D.; Kamenidou, I., 2014: Purchase Decisions of Greek Consumers: An Empirical Study. Procedia Economics and Finance, 9: 456-465. doi: https://doi.org/10.1016/S2212-5671(14)00047-1.

21. Ramya, N.; Mohamed Ali, S., 2016: Factors affecting consumer buying behavior. International Journal of Applied Research, 2 (10): 76-80.

22. Rani, P., 2014: Factors influencing consumer behaviour. International Journal of Current Research and Academic Review, 2 (9): 52-61.

23. Sinclair, S. A.; Hansen, B. G., 2007: The relationship between purchase decisions and quality assessment of office furniture. Wood and Fiber Science, 25 (2): 142-152.

24. Susjan, A.; Lah, M., 1996: The relevance of the procedural choice theory for the consumer behaviour in transition economies. $4^{\text {th }}$ Annual Proceedings of the Conference on Marketing Strategies for Central and Eastern Europe, December 4-6, 1996, Vienna, Austria.

25. von Helversen, B.; Abramczuk, K.; Kopeć, W.; Nielek, R., 2018: Influence of consumer reviews on online purchasing decisions in older and younger adults. Decision Support Systems, 113: 1-10. doi: https://doi.org/10.1016/j.dss.2018.05.006.

26. Warayuanti, W.; Suyanto, A., 2015: The Influence of Lifestyles and Consumers Attitudes On Product Purchasing Decision Via Online Shopping In Indonesia. European Journal of Business and Management, 7 (8): 74-80.

27. Xu, B.; Chen, J., 2017: Consumer purchase decisionmaking process based on the traditional clothing shopping form. Journal of Fashion Technology \& Textile Engineering, 2017.

28. Zadnik Stirn, L., 1998: Conjoint analysis to incorporate public opinion into forest management modeling. Paper presented at the IUFRO Division 4. International symposium, Roma-Ostia.

29. Zwierzyński, P., 2017: The determinants of consumer behaviours in the furniture market. Annals of Marketing Management \& Economics, 3 (1): 131-143.

\section{Corresponding address:}

\section{PETRA GROŠELJ}

University of Ljubljana

Biotechnical Faculty

Jamnikarjeva ulica 101

1000 Ljubljana, SLOVENIA

e-mail: petra.groselj@bf.uni-lj.si 